\title{
Coexistence of supply chains in a city's food supply: a factor for resilience?
}

\section{Yuna Chiffoleau $^{1} \cdot$ Anne-Cécile Brit $^{2} \cdot$ Milo Monnier $^{3} \cdot$ Grégori Akermann $^{1}$. Maxime Lenormand ${ }^{3}$. Florent Saucède ${ }^{4}$}

Received: 19 February 2019 / Accepted: 20 July 2020/Published online: 7 September 2020

(C) INRAE and Springer-Verlag France SAS, part of Springer Nature 2020

\begin{abstract}
The objective of this article is to propose and test an approach to characterise a city's supply system and analyse its resilience. Anchored in economic and network sociology, the approach has been enriched by contributions from management sciences and geomatics, which have made it possible to conceptualise a city's supply system as a network that is both social and spatialised, structured by operators and circulating differentiated products. Tested in the city of Montpellier, a signatory of the Milan Pact, this research was based on the production of primary data from a variety of sellers and suppliers. While confirming the complementarity between short and long supply chains, the results show more broadly how the articulation of three spatialised markets favours the resilience of the city's supply, even if it is also a source of vulnerability. Therefore, these results make an original contribution to the intersection of research on the resilience of urban supply and on coexistence in food systems, while also calling for further research.
\end{abstract}

Keywords Food supply $\cdot$ Cities $\cdot$ Supply chains $\cdot$ Resilience $\cdot$ Multi-disciplinary

\section{Introduction}

"When you think that every day, for a city the size of London, you must produce, import, sell, cook, eat and sell enough food for 30 million meals, and that something

Yuna Chiffoleau

yuna.chiffoleau@inrae.fr

1 Innovation, Univ Montpellier, CIRAD, INRAE, Institut Agro, Montpellier, France

2 FR CIVAM Bretagne, Pôle INPACT, 17 rue du Bas Village, CS 37725, 35577 Cesson Sévigné Cedex, France

3 TETIS, Univ Montpellier, AgroParisTech, CIRAD, CNRS, INRAE, Montpellier, France

4 MOISA, Univ Montpellier, CIRAD, CIHEAM-IAMM, INRAE, Institut Agro, Montpellier, France 
similar has to happen every day for every city in the world, it is remarkable that those of us who live in these cities simply manage to get food" (Steel 2008). Food supply in cities is a critical issue in the context of increasing global urbanisation. Often restricted to private actors in Northern countries, it has not been considered a major issue until recently, which explains the lack of public data on the food flows that feed cities (Bognon 2015; Brand 2015). From the 2000s onwards, the emergence of urban food policies has served as a reminder of the challenge of securing urban food supply and has given rise to a new research and regional planning agenda concerning this issue (Morgan and Sonnino 2010; Brand 2015). In line with the commitments made in the 2015 Milan Pact, major cities have thus become important actors in the broader movement to re-localise food, based on the development of peri-urban agriculture and the renewal of short food supply chains (Brand 2015; Sonnino 2016; Chiffoleau 2019). However, recent episodes of stock shortages in supermarkets, such as those that followed the blockades of central purchasing offices in France in $2019,{ }^{1}$ have raised the question of urban food supply resilience when faced with possible disruptions. This question has become a major issue for many political decision-makers, and also for citizens, within the context of the shortages observed or feared during the COVID-19 crisis that has affected the entire planet in 2020. However, the resilience of urban food supply goes beyond the challenge of ensuring sufficient food provisions and refers more broadly to the ability over time of a food system and its multi-level entities to provide appropriate and accessible food for all in the face of varied and even unexpected disruptions (Tendall et al. 2015), i.e. ensuring food security. Within the context of urbanisation, and increasing disruptions (pandemics, natural disasters, strikes, etc.) as well, food security is no longer a problem for Southern countries alone (Linou 2019). ${ }^{2}$ Recent studies have called for an analysis focused on the supply systems for regions and cities in particular, to better address the capacity of these systems to ensure food security (Smith et al. 2016).

From this perspective, the aim of this article is to propose an approach, based on a case study in France, to characterise a city's supply system and, using this as a basis, to show how the coexistence of spatialised food chains and markets ensures its resilience. By combining contributions from economic sociology, management science and geomatics, we propose a new conception of a city's supply as a system of actors, social relationships and spatialised flows distributing differentiated products. On this basis, we describe the supply system for the city of Montpellier, in the south of France, using the example of fresh tomatoes during the production season (June-September), and we estimate the associated volumes. While the complementarity between long and short local chains is an important factor in guaranteeing the supply of tomatoes at the city level, we show more broadly that the resilience of the city's supply relies on the articulation of three types of markets. This article thus expands upon work on the coexistence of models in the agricultural and food sector, which has focused on the coexistence of a diversity of agriculture in value chains and territories (Hervieu and Purseigle 2015; Polge et al. 2018). This exploratory study can also help public

\footnotetext{
${ }^{1}$ Part of the "yellow vests" protest movement that arose in France in October 2018 following the government's plan to increase the price of petrol.

${ }^{2}$ This is also reflected in the draft resolution on the food resilience of regions and national security brought before the French Senate on 20 June 2019.
} 
decision-makers and even citizens to take on the issue of food security in cities and, more broadly, to regain control over their food within the context of COVID-19 postcrisis.

In the first part of this article, we put forth a brief state of the art on works concerning urban supply, presenting the three main approaches developed on this theme and showing how these approaches integrate, in a more or less explicit way, the issue of resilience. In the second part, we present the multi-disciplinary analytical framework through which we propose characterising a city's supply system and analysing its resilience, through three main criteria. We then explain the method that we have implemented, using the city of Montpellier as a scale. In the third part, we present the results obtained with fresh tomatoes, an essential product in French diets. ${ }^{3}$ We conclude by focusing on the originality of our multi-disciplinary approach and our results, at the intersection of work on urban food supply and its resilience on the one hand, and on the coexistence of agricultural and food systems on the other, while highlighting the limits of our research.

\section{From urban food supply to the resilience of cities' supply system, a field of work under construction}

Recent work on urban food supply is organised around three types of approaches, which highlight different criteria of vulnerability or resilience concerning this supply: (i) the approach based on foodsheds; (ii) the approach based on material flows and urban metabolism; and (iii) the approach based on supply strategies and chains, in which we position our study by combining a socio-economic and spatial approach. This article addresses the three different approaches through a literature review conducted by researchers or professionals in the fields of planning, urban development and local government consulting.

\section{Assessing cities' food self-sufficiency, an initial approach through foodsheds}

The term foodshed, analogous to a watershed, refers to the geographical space used to produce food for a city (Peters et al. 2009a). This metaphor was first used in the late 1920 s by the director of the port of New York to note that "the barriers which guide and control movements of foodstuffs are more often economic than physical" (Hedden 1929). The term was mainly used from the 1990s onwards, to promote alternatives for reconnecting agriculture carried out near cities and the food supply of urban dwellers (Kloppenburg et al. 1996). It is used more broadly as a concept that enables us to question the impacts of food systems on the environment concerning climate change and the reduction of fossil fuel stocks, but also in terms of reducing the food supply vulnerability to these disruptions (Peters et al. 2009b). Often employed by geographers, planners or urban developers to support the implementation of urban food policies, the foodshed approach generally consists of comparing a city's consumption with the agricultural production located nearby (Horst and Gaolach 2015). The concept relies

\footnotetext{
3 The tomato is the most consumed vegetable in France, with an average annual consumption of $15 \mathrm{~kg}$ per capita (FranceAgrimer 2018).
} 
on Geographic Information Systems (GIS) and land use data to assess local production (actual or potential) and demographic data to estimate consumption in urban centres (in calories or tonnes). Other variables can be added to refine the estimates, such as agricultural yields (Zasada et al. 2019) or the socio-demographic profiles of urban dwellers and their associated diets (Marie et al. 2017). The approach often leads to the calculation of food self-sufficiency scores, allowing the comparison of several cities (Zasada et al. 2019) or, in a prospective approach, the testing of different supply and demand evolution scenarios for strengthening food autonomy in cities (Kremer and De Liberty 2011; Darrot 2014). Although these works do not directly refer to the concept of resilience, the implicit assumption is that, for a city, the existence of diversified local agriculture distributed across short chains is an important criterion for coping with possible disruptions.

\section{Tracking and reconnecting material flows, an approach based on urban metabolism}

Urban food supply can also be analysed through another type of approach, initiated in the 1960s and revived in the early 2000s, in connection with the emergence of the field of regional ecology research and action (Barles 2017): the urban metabolism approach. Redefined as a city-scale offshoot of territorial metabolism, urban metabolism reflects the interactions between city and biosphere, and corresponds to the expression of raw material flows (water, fossil fuels, foodstuffs, etc.). It integrates incoming, internal and outgoing flows, as well as their vectors (roads, pipes, etc.), with the aim of better understanding the origin of flows for a given region, their organisation by stakeholders and their economic, social and technical consequences (Debuisson 2014). In France, the quantification of flows is based on the SitraM database, listing the volume of goods transported between 21 French regions ${ }^{4}$ and to/from abroad via different modes of transport (sea, rail or trucks over 3.5 tonnes). While these data make it possible to estimate the main flows of commodities between regions as well as the flows of associated chemical components such as nitrogen, phosphorus and so on (Billen et al. 2009, 2012), they do not include the volume transported by small vehicles. Moreover, they do not enable measuring the share of infra-regional supply, nor knowing with certainty the origin of products: for each group of commodities (fruits and vegetables, meat, etc.), the database gives the destination, i.e. the region of unloading, as well as the origin, which in this case corresponds to the last region (or country for imported products) of loading, which does not necessarily mean the region in which the commodities were produced. However, this approach based on flows, which is complementary to the foodshed approach, makes it possible to assess the spatial disconnect between production and consumption basins and, on this basis, to propose innovative ways of relocating flows at a territorial scale in order to increase food self-sufficiency (Tedesco et al. 2017). The explicit hypothesis in such literature is that low dependence on inputs from outside the territory is a criterion of resilience for the local economy. This approach thus constitutes a second entry into the theme of a

\footnotetext{
${ }^{4}$ The regions addressed in the SitraM database are the result of groupings between departments and do not correspond to either the old or the new division of administrative regions in France.
} 
city's food supply resilience, which calls for the quantification of a city's dependence regarding the different territories that supply it.

\section{Characterising strategies and supply chains at a system level}

A third type of approach to a city's supply and resilience is based on an analysis of the supply chains that make commodities accessible. The concept of resilience has gained prominence in the literature on supply chain management, although it is still an emerging area of research (Hohenstein et al. 2015). Analysis highlights several factors of resilience at the scale of these chains, such as agility, visibility, flexibility, redundancy (i.e., in particular, multiple supply sources), reduction of complexity and uncertainty, inter-organisational collaboration, integration, transparency or knowledge of the structure of supply chains (Pettit et al. 2013). From this perspective, the implementation of resilient supply chains is based on the decisions of operators who must decide, according to a cost-benefit analysis, between increasing their capacities and exposing themselves to potential vulnerabilities. This approach by the operators, considered in isolation, and by the supply chains set up, has been used, for example, in Baltimore to identify the factors of resilience for the city's supply following a hurricane (Hecht et al. 2018). The analysis carried out in Rockhampton and Brisbane in Australia following floods that cut roads and bridges (Smith et al. 2016) goes along the same lines. It shows how, in the face of such disruptions, some supply chains have proved more resilient, leading to the identification of four factors: the geographical scale of supply, with the distance travelled increasing the likelihood of being impacted by road infrastructure disruption; the diversity of actors and skills within the chain, influencing the ability to implement solutions; their responsiveness, i.e. their ability to implement solutions quickly; and lastly, the cohesion of the chain, which is addressed along two dimensions, intra-network, linked to interpersonal relations between the actors in the chain, and inter-network, based on relations between the chain and other organisations, in particular suppliers other than those usually used and institutions. Thus, short supply chains are assumed to have strong intra-network cohesion and weak inter-network cohesion, unlike long chains. From this perspective, the resilience of the supply system at the city scale is conceived as the sum of the resiliencies of the chains that enable supply. This approach highlights the complementarity between different chains, but the dependencies between operators and between chains, as well as their common vulnerabilities, have hardly been addressed.

Other diagnoses seek to integrate these interdependencies to a greater extent, by underlining, in particular, the nodal points for the transport of goods towards or within a city: the study carried out in Bristol, for example, shows the key role of the port and the wholesale market (Carey 2011). On the city scale, the most systemic diagnosis that we have identified was carried out by a public entity for New York City: on the basis of a qualitative, quantitative and spatial approach, the study integrates the analysis of supply chains and routes, shows the central role of a wholesale market situated in a flood zone on the basis of a quantification of the flows and maps the relationships between the operators (NYCEDC and NYCMORR 2016). While our study is a direct continuation of this work, our objective is to strengthen the theoretical and methodological bases of such a systemic approach to the resilience of a city's supply by combining several disciplines. 


\section{A multi-disciplinary analytical framework for a city in search of food self-sufficiency}

\section{City food supply as an embedded system}

The analysis brought forth here is firstly part of economic sociology, starting from the principle, in line with Karl Polanyi (1944), that economic activity, like all social action, is embedded in social structures that shape its form and condition its effects (Granovetter 1985). In the Anglo-Saxon tradition- economic and network sociology-the emphasis is on embedding in social relationships, and in interpersonal relationships in particular, which, when taken into account, enriches the analysis of the functioning of markets (Granovetter 1973). A city's supply can then be analysed as a system of relations, structured at a minimum on the basis of exchanges between sellers and suppliers. These exchanges may be limited to a one-off interaction of an economic nature or they may be repeated, include a personal dimension, include solidarity between actors, and so on, and thus define, in line with Granovetter's work, a "strong”' link (Degenne and Forsé 1994), which Smith et al. (2016) address through the idea of intra-network cohesion. However, these relationships are not spontaneous and they depend on the entrepreneurs' strategies (Favereau and Lazega 2002). As such, their analysis calls for a convergence with management sciences, which show how these strategies, with regard to supply chains, are linked to brands, (differentiated) products, and to the skills of the actors, their commitment (Saucède 2010) and their consideration of resilience issues (Stolt and Grant 2017). The link between economic sociology and management sciences thus makes it possible to view a city's supply as a system of actors and social relationships between sellers and suppliers, structuring supply chains.

However, these two disciplines take little account of the fact that supply chains are also part of a geographical space that is both a resource and a constraint, particularly from the point of view of resilience. The additional challenge is then, with the help of geomatics ( $\mathrm{Li}$ et al. 2013), to approach the resilience of the supply system through a set of geographical data locating the infrastructure and sites mobilised (roads, warehouses, food production sites, etc.) in order to take into account their capacity to withstand various risks. By enhancing the viewpoint of economic sociology with contributions from management sciences and geomatics, we can thus characterise a city's supply system as a system of actors, social relationships and flows, mobilising infrastructures and sites located in the geographical space and circulating differentiated products. This framework allows us, in line with previous work, both to expand the hypothesis that the coexistence of different food models fosters the resilience of the food supply and to propose a method for analysing it.

\section{From the coexistence of food chains to the resilience of the supply system}

The notion of coexistence in research on the agricultural and food sector now structures a field of work concerned with the complementarity, confrontation and hybridisation of different agricultural and food models (Gasselin 2017). While analyses have so far focused mainly on the plurality of agricultural models, the article by Fournier and Touzard (2014) is a major contribution to the topic at hand: it supports the idea that the coexistence of different food models within a concrete food system can promote food security. Alongside the dominant agro-industrial model, which is capable of mass production but sensitive to 
changes in global markets, the analysis highlights the interest of "alternative" models, which are more sensitive to climatic or food safety risks, but which contribute to strengthening regional food autonomy. In order to assess the resilience of a city's supply, the challenge would then be to see how this resilience is based on different models. However, the work mentioned above shows that there is a possible diversity within the same model: in the case of the floods in Australia, Smith et al. (2016) show, for example, how some supermarkets, an a priori part of the agro-industrial model, were able to directly mobilise producers and alternative means of transport when faced with road transport disruptions that blocked their central purchasing offices: the strong inter-network cohesion of the long chains finally enabled them to operate in short chains. This led Smith et al. to propose overcoming the dichotomy between long chains and short chains.

We then propose an analysis of the concrete chains that are mobilised and which can be mobilised to supply a city. A chain here refers both to the relationships between actors and to the flows of products circulating between different places. We hypothesise that the description of these chains, by revealing the relationships between actors and the spatialised flows, allows us to contribute to the analysis of the resilience of a city's supply: on the one hand, these chains, through their three dimensions (actors, relationships and flows), are each a source of resilience and vulnerability, and on the other hand, they structure a system of interdependencies and common dependencies that can strengthen or, on the contrary, weaken the food supply on a city scale, all the more so in the event of disruptions. In line with Tendall et al. (2015), the characteristics of the products supplied must also be taken into account, which previous studies have not done, in order to assess the capacity of this system to ensure the supply of an offering that is appropriate (healthy and nutritious products, adapted to the needs and food preferences of consumers) and accessible (physically and in terms of price).

By cross-referencing the hypotheses of work on foodsheds, urban metabolism and supply chains, and by enriching them with our socio-spatial approach with a focus on product characteristics, we then propose addressing the resilience of a city's supply system through three main criteria: (i) the diversity of suppliers and their location in space, in current situations and in the event of a disruption (the current or possible use of a multitude of actors and locations reduces the vulnerability of the system); (ii) the balance between local and non-local products, short and long chains (food autonomy is a source of resilience; external inputs help to provide a supply that is appropriate and accessible to all); and (iii) the intensity of links within supply chains (a strong link is more likely to be maintained in the event of disruption) and the morphology of the network formed by the relationships between actors in the city's supply system (a small number of intermediaries between producers and sellers at the city level can be a source of vulnerability) (Burt 1995).

\section{The development of a mixed method at the city level}

Our study concerns the consumption basin of the city of Montpellier (400,000 inhabitants), located in the south of France. This basin corresponds to the area in which the people of Montpellier live and obtain their supplies preferentially. The objective, in fact, was to capture the perimeter that accounts for the population's habits, even if this does not coincide with the areas of public action (Marie et al. 2017). The studied area thus includes the municipality of Montpellier as well as 12 bordering municipalities (Fig. 1) featuring an urban continuity with the city and having a supermarket and/or a 


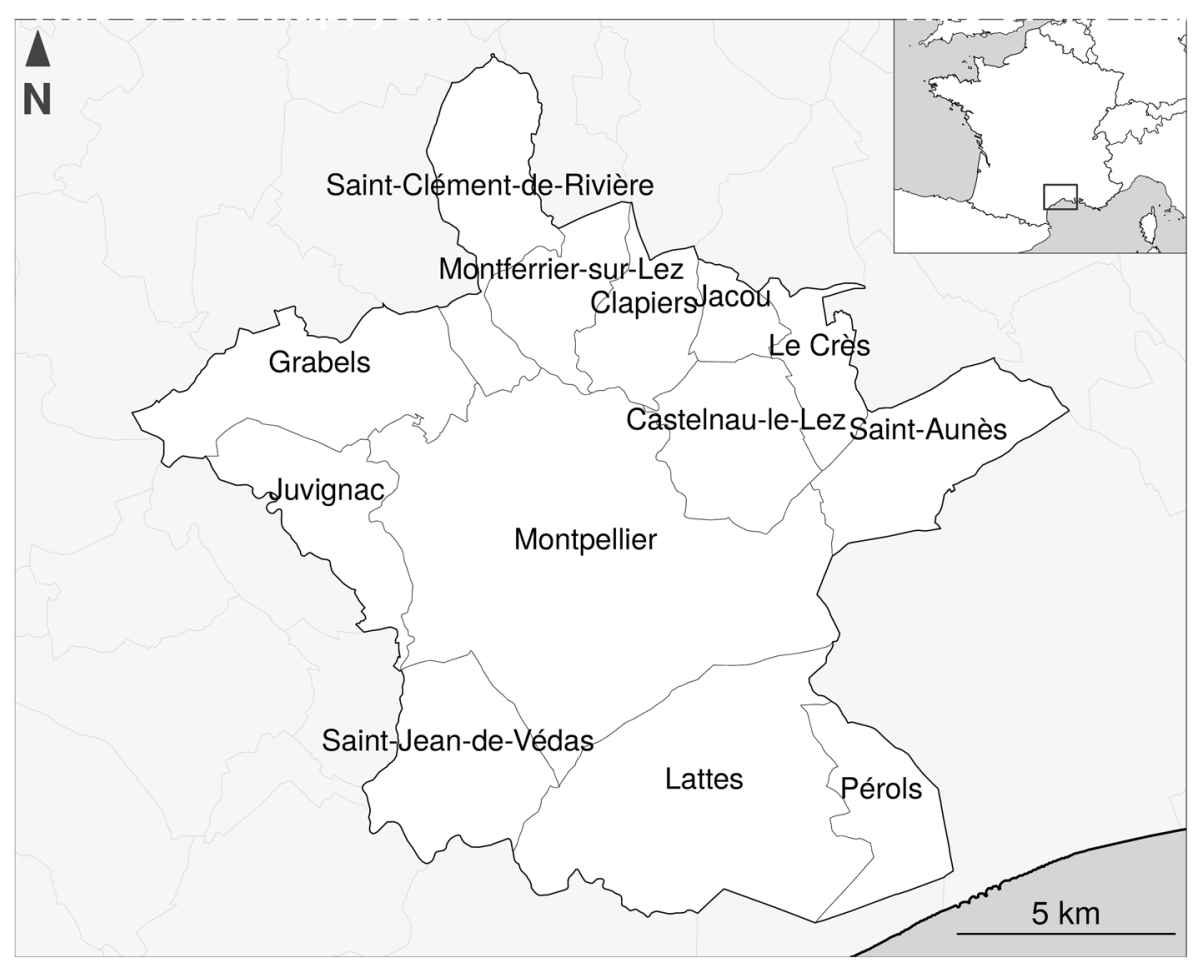

Fig. 1 Area of study. Sources: BD TOPO IGN 2018 and authors. Realised with sf 0.8 .0 and cartography 2.4.1 $\mathrm{R}$ packages

highly frequented road axis for home/work/leisure trips along which consumers frequently make food purchases (Douard et al. 2015).

This city was chosen for two main reasons: first, Montpellier, one of the initial cities to sign the Milan Pact in 2015, illustrates the case of large cities committed to the development and promotion of local food; and second, as our team is based in Montpellier, we developed relationships with many operators in the city's supply chains, which should facilitate data collection.

In order to analyse the concrete chains mobilised from a qualitative, quantitative and spatial perspective, we conducted our study on only a few products, namely tomatoes. This product is highly consumed and not easily substituted, and guaranteeing its availability represents a major challenge for sellers. The study began by contacting various organisations concerned (City of Montpellier, Chamber of Commerce and Industry, etc.), with the aim of obtaining secondary data on points of sale, operators' strategies and associated volumes. This first step confirmed the lack of quantitative data on food flows, already highlighted in the literature on urban food policies (Bognon 2015; Brand 2015), as well as the lack of upto-date data on the points of sale located in the city.

We then sought to make an inventory of the points of sale offering tomatoes in our area of study using the only public database available, the SIRENE database. ${ }^{5}$ This

\footnotetext{
${ }^{5}$ Système national d'identification et du répertoire des entreprises et de leurs établissements, database managed by INSEE, Institut National de la Statistique et des études économiques.
} 
database, however, lists the companies at the time they start their activity but they are not immediately removed if their activity ceases. Moreover, companies registered in the SIRENE database with an APE code (Principal Business Activity code) that are not involved in the sale of food products may still carry out this activity. Finally, this database does not include non-shop points of sale: open-air markets, covered markets, farm stands, etc. To identify the latter, incompletely accounted for by municipal services, and add them to the SIRENE database, we cross-referenced different sources of information (tourism office, a guide promoting short chains, etc.) and visited each market to count the stands offering tomatoes and specify the nature of the associated sellers (producer, retailer). In the end, we established 499 as the number of points of sale offering tomatoes in the area of study, in or out of shops, corresponding to 595 sellers.

The sample surveyed was adjusted as the study progressed, according to the differences observed between the SIRENE database and the reality on the ground (shops that had disappeared or did not offer fruits and vegetables) but also according to the willingness of the sellers to respond to our survey. We sought to cover the entire area of study and to question a diversity of actors within each point of sale category, while over-representing shops managing large volumes (supermarkets) or, according to our initial surveys, developing contrasting sourcing strategies (greengrocers, organic shops). A total of 81 points of sale were surveyed, representing 90 sellers and three categories of trade: organised distribution (including INSEE categories integrated trade and organised independent) (26), independent in-shop distribution (32), independent out-of-shop distribution (23) (Fig. 2).

The surveys at these points of sale were based on an interview with the head of the fruits and vegetables department, or the person in charge of the shop or stand, as well as

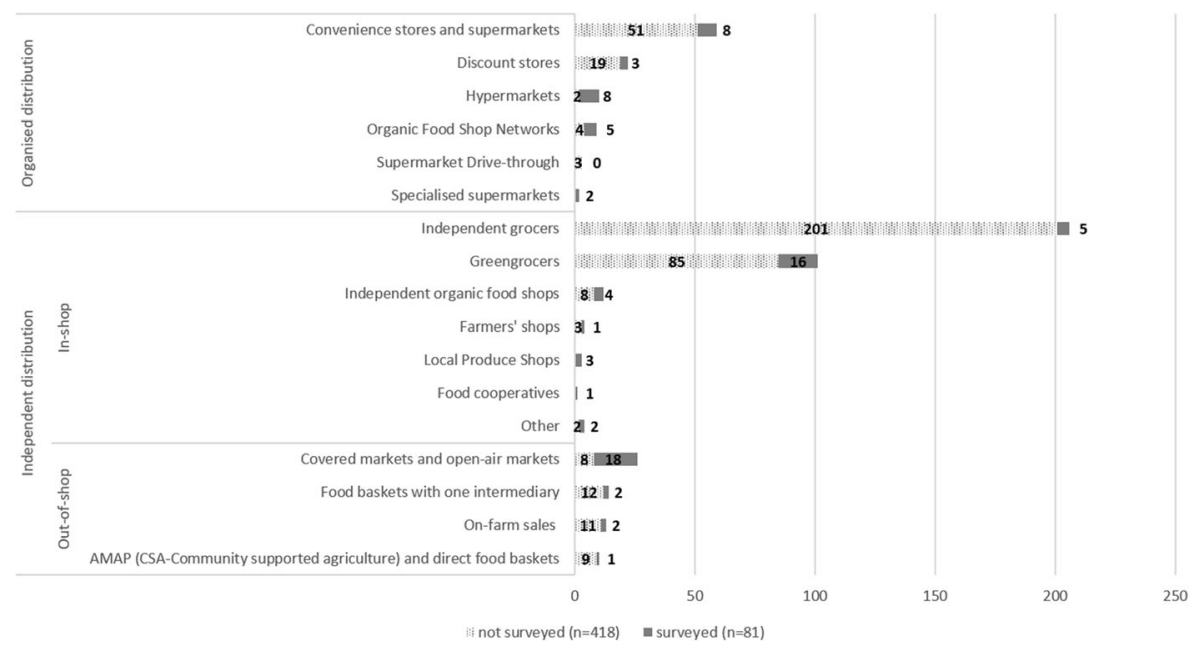

Fig. 2 Estimated number of tomato points of sale and sample surveyed. Source: SIRENE and authors. NB. GSSA: Grande Surface Spécialisée Alimentaire (supermarket specialised in the sale of fresh food products). The 'Other' category refers to points of sale whose main activity does not concern products such as tomatoes (gardening shop, bulk shop). Out of the 4 covered markets and 22 open-air markets surveyed in the area of study, we counted 89 stands offering tomatoes (38 producers, 51 retailers). Of these, 10 producers and 12 retailers were interviewed 
Table 1 Survey grid for points of sale (or stands, in the case of open-air markets and covered markets). Source: authors

\begin{tabular}{|c|c|c|}
\hline \multirow[t]{3}{*}{$\begin{array}{l}\text { Topics of } \\
\text { the interview }\end{array}$} & Suppliers & $\begin{array}{l}\text { General: names, category (producer, } \\
\text { wholesaler), products supplied } \\
\text { (proportion, quality) } \\
\text { Supply: frequency, means of transport } \\
\text { Choice: strategy, important criteria } \\
\text { Relationships maintained } \\
\text { Changes during the year }\end{array}$ \\
\hline & Product management & $\begin{array}{l}\text { Choice of products: criteria } \\
\text { Storage conditions and duration } \\
\text { Volumes for each type of product } \\
\text { Loss management }\end{array}$ \\
\hline & Resilience & $\begin{array}{l}\text { Response to supply problems that } \\
\text { have already occurred } \\
\text { Anticipation of future supply problems } \\
\text { (problems considered, solutions envisaged) }\end{array}$ \\
\hline \multirow[t]{2}{*}{$\begin{array}{l}\text { Information collected } \\
\text { on the shelf/on the stand }\end{array}$} & Products & $\begin{array}{l}\text { Number of references per product } \\
\text { Brands on the shelf }\end{array}$ \\
\hline & Display & Display on the origin, quality, prices \\
\hline
\end{tabular}

on observing the products and how they are displayed within the shop or stand (Table 1).

We then conducted interviews with 17 of the suppliers mentioned (out of 73, Fig. 3), in order to cross-reference the information. The surveys were conducted from June to September 2018, which corresponds to the peak tomato production season in France and in the Montpellier area. The method was adjusted after some initial surveys, with a group of experts, sellers and representatives of institutions. The results were presented in January 2019 at a meeting with some 20 stakeholders, including people interviewed during the survey, which made it possible both to validate the extrapolation of the data collected and to understand the unifying potential of a discussion on the resilience of the city's food supply.

\section{From a supply chain analysis to the identification of interconnected markets that favour resilience}

\section{An opaque diversity of tomatoes from a limited number of suppliers}

Except for covered markets and open-air markets where data could not be collected from all the sellers, the points of sale surveyed offer, on average, five different types of tomatoes. For the sellers, the tomato is an appealing product that "must take hold a place on the stands" $" 6$ and requires diversity. These types of tomatoes, both in shops and market stands, are differentiated by name ("round tomato", "beef tomato", etc.), origin

\footnotetext{
${ }^{6}$ The texts in quotation marks are taken from discussions collected during the surveys.
} 


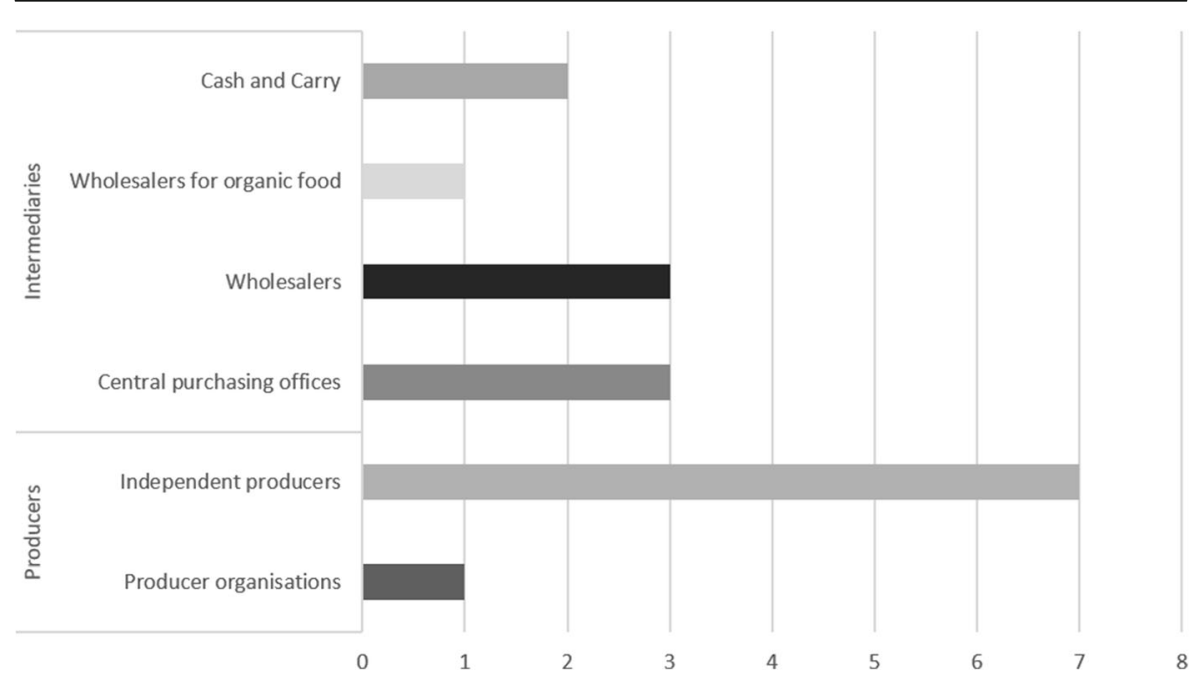

Fig. 3 Suppliers surveyed

(at a minimum, the country must be indicated), price and appearance. Commercial types generally correspond, in supermarkets and specialised supermarkets, to modern hybrid varieties which are the most commonly consumed tomatoes (round tomato, bunch tomato, etc.). Some of these modern varieties produce tomatoes whose appearance, without regards to taste, is similar to those from old varieties, commonly observed in-season on the stands of producers at markets. Regularly covered in the media, the difference between "true" and "false" old varieties is not communicated in shops. This, from the point of view of food supply resilience, without posing a problem in terms of quantity, puts into question the ability of certain chains to provide products that fit the food preferences of consumers, who seek out old varieties for their taste (Debarle 2019). In the same vein, concerning geographical origin, it is not uncommon for a tomato from a variety selected for its shelf life - supplied by a central purchasing office and originating in Brittany - to be found alongside a tastier tomato supplied directly by a local producer on a supermarket shelf, both displaying the same "French origin" indication, without any information to differentiate them. Local supply, observed in all the supermarkets surveyed, is in fact still generally undervalued, in both integrated and organised independent trade, as previous studies have shown (Brand 2015). This is more the case in independent in-shop distribution, which often indicates the place or region of production on shelf labels. On the other hand, the origin of tomatoes is rarely specified beyond the country of origin at open-air market stands. Once again, this lack of information does not affect the quantity of supply, but can be a source of vulnerability: as one of the actors interviewed described to us, in the event of a food safety problem observed in a production region, for example, consumers will not have sufficient information to know whether they can continue to buy tomatoes safely. Problematic batches of tomatoes will be quickly withdrawn, but the information on other tomatoes will not be improved, which may raise doubts among consumers.

Moreover, apart from producers at open-air markets, AMAPs (Associations for the Preservation of Local Farming) or directly at farms, where we did not observe any inseason purchase and resale of tomatoes, a third of sellers (21 out of 63) say they have 
only one tomato supplier and the same number say they only have two suppliers, with no direct link to the volume sold. This, according to some respondents themselves, implies a certain vulnerability for the point of sale concerning the supply of this product and may be surprising in view of the importance of this appealing product. We also noted that one of the suppliers identified supplies nine (out of 63) of the points of sale surveyed apart from open-air markets and covered markets, under a normal situation for seven of them and in case of an emergency for the other two. Moreover, 30 of the businesses surveyed obtain their supplies from the producers' section of the city's National Interest Market (MIN), which brings together about ten tomato producers in season. This may reveal a relative dependence of the sellers on certain actors but also on this place of exchange. We will come back to this point. While noting that supply disruptions have already occurred, only three sellers reporting only one supplier (3 out of 21) mentioned having a "plan B", with which they often have a strong link. On the other hand, other sellers have both several suppliers and a plan B. This plan B is usually a local producer or wholesaler, such as the one mentioned above, specifically seeking to differentiate themselves by responding to emergency requests. However, it is not always possible for sellers to diversify their suppliers: in particular, for businesses linked to mass distribution, integrated businesses have more limited room for manoeuvring than organised independent businesses in theory, as their managers or department heads are required to obtain most of their supplies from a central purchasing office. The survey, however, did not reveal any significant differences between these two types of shops in terms of tomato supply, as some integrated shops may, for example, obtain most of their tomatoes from a local wholesaler. Some purchasing managers in both integrated and organised independent trade stated that they wanted to diversify their supply sources in order to address possible disruptions but also to buy more local food in order to meet what they assessed as a growing demand. Therefore, some do not hesitate to go beyond what is recommended and commit themselves, often in their spare time, to approaching other suppliers, particularly local producers.

\section{Supply chains mobilising flows across France}

Starting from the 81 points of sale and the 90 sellers surveyed, we were able to trace 257 flows contributing to the tomato supply in Montpellier (Fig. 4): here, a flow corresponds to the transfer of tomatoes between two different locations, carried out either between two operators (supplier to seller) or by a single operator but between two different locations (such as a producer going to an open-air market to sell tomatoes there).

First of all, the representation of these flows makes it possible to visualise three major production areas supplying the city with tomatoes in season: the first corresponds to the Montpellier production basin (an irrigated plain historically specialised in market gardening for shipment), with a large number of direct flows between producers located less than $80 \mathrm{~km}$ from the centre of Montpellier and points of sale (83 flows out of 257). This $80 \mathrm{~km}$ distance is commonly used at present to define a "local" product (Chiffoleau 2019). The two other major areas of origin are the south-west region (the irrigated Garonne valley) and Brittany. However, we also observed a significant number of flows from intermediaries located in Provence (wholesalers present in the MINs of Châteaurenard and Cavaillon). These may possibly be supplied in the production basin of Montpellier but generally speaking, in season, we do not observe 


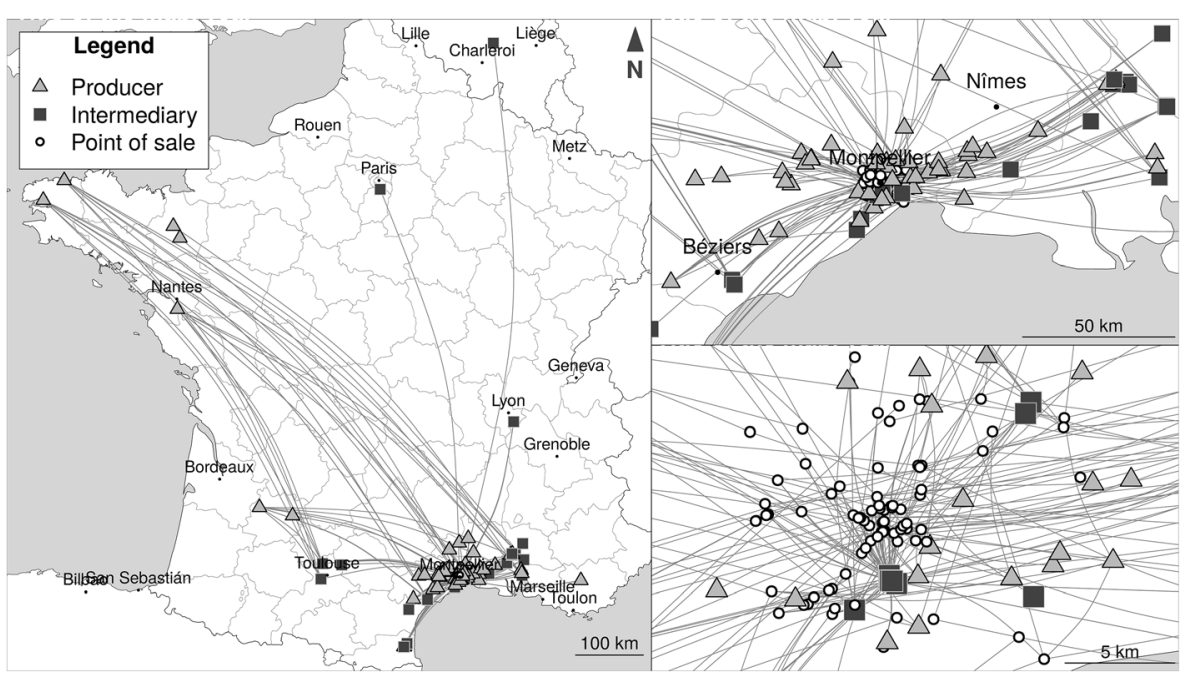

Fig. 4 Flows of in-season tomato supply for Montpellier. Source: IGN (2018) and authors. Realised with igraph 1.2.5, sf 0.9.4 and cartography 2.4.1 R packages

any flow of tomatoes produced near Montpellier and transported over long distances before returning to the points of sale in Montpellier. We can nevertheless note the importance of flows from Brittany in season, which can be explained by the presence in this region of two of the three largest tomato producers in France. Moreover, while the supply from Spain or Morocco appears negligible in season, it is, according to the interviewees, significant in the off-season.

In terms of the resilience of the supply system, this representation underlines the possible dependency of the city on certain production sites but puts into perspective the vulnerabilities linked to transport for supply. We will put these dependencies into perspective by extrapolating the volumes associated with different origins on the scale of the city.

\section{Food supply chains structured into three sub-networks}

An analysis of the relationships between sellers, intermediaries and producers that underpin Montpellier's tomato supply chains also reveals a network made up of three sub-sections in which the players are closer to each other than to the other members of the network ${ }^{7}$ (Fig. 5).

First of all, the network analysis enables us to visualise short food chains, corresponding to seller-producer relationships, and long chains, linking the point of sale to a wholesaler or a central purchasing office. Within this network, however, even in short chains, the links may be weak (a relationship limited to a commercial exchange) or strong: for example, some independent businesses differentiate themselves by committing in advance to buying from local producers, by helping them to plan their production and/or by supporting them in the event of production contingencies, preferring to explain to consumers the reasons for a stock shortage rather than asking

\footnotetext{
${ }^{7}$ In network analysis, two actors are considered to have a closer relationship when the path connecting them is shorter (direct relationship or limited number of intermediaries) (Degenne and Forsé 1994).
} 


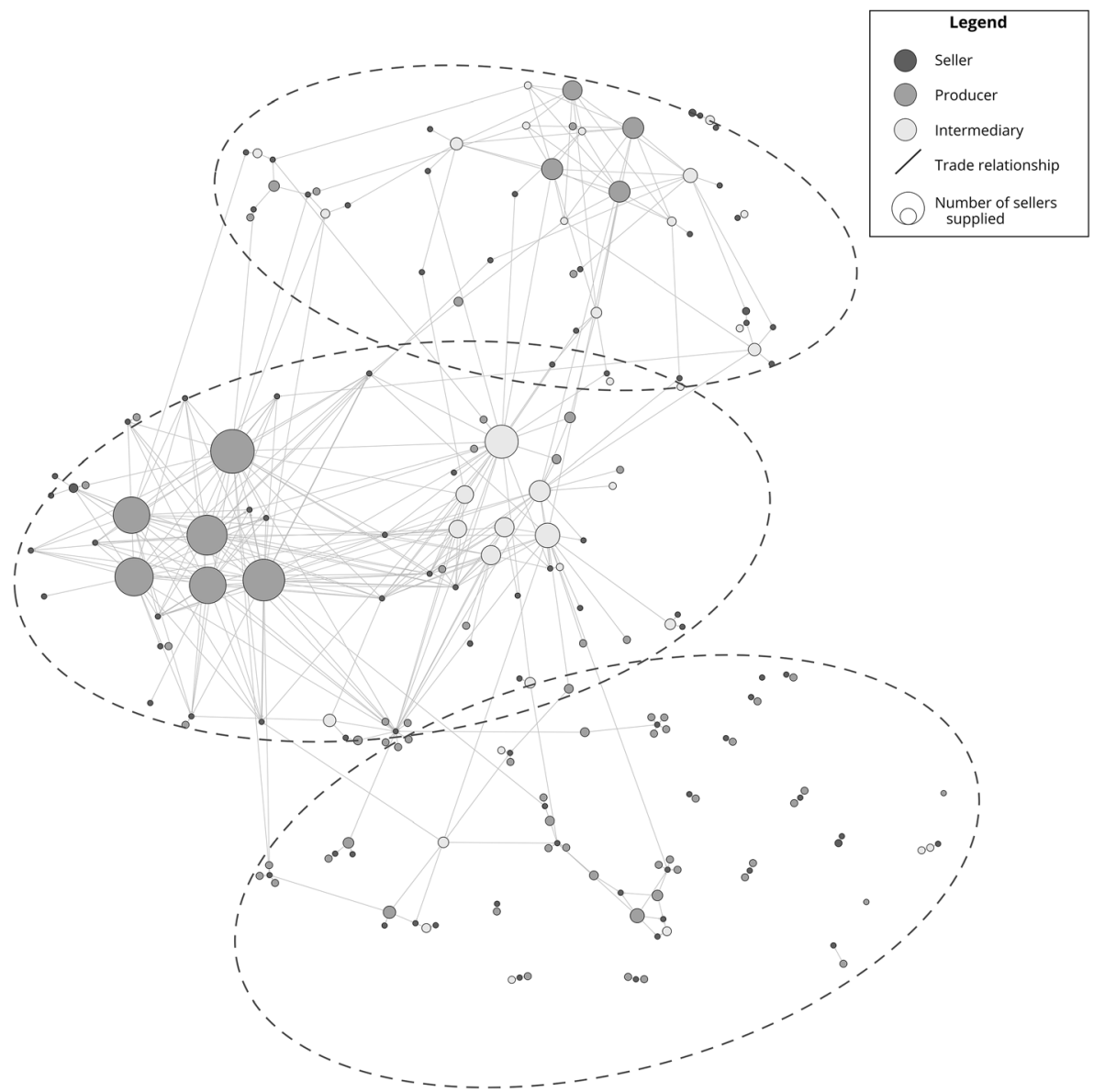

Fig. 5 Network of relationships between actors involved in supplying Montpellier's points of sale with inseason tomatoes. Source: Authors. NB. Number of relationships $=370$; relational data processing with Gephi

for a "plan B". In other cases of short chains, particularly those observed in the case of supermarkets buying directly from producers for certain tomatoes, the strategy is more often opportunistic and the relationship is weak. Above all, we can see that several producers and middlemen are at the centre of the network, in a position as a crossing point: on the one hand, they concentrate a large number of relationships, supplying many points of sale in Montpellier, and on the other hand, they make the link between the two other sub-parts of the network that are poorly connected (Burt 1995). This representation highlights the key role of a few actors in particular in the resilience of the city's supply. However, this can be nuanced by the fact that these actors are grouped together in the same place, the Montpellier MIN, which can be a vulnerability.

\section{An analysis of the chains that reveals the coexistence of three interconnected markets}

By cross-referencing data on the strategies, flows and relationships between the actors behind Montpellier's tomato supply, we propose going beyond the framework of 
supply chains and report on the different "markets" that supply the city. By "market", we mean, within the meaning in Anglo-Saxon economic sociology, a system made up of companies with similar strategies and interacting preferentially with each other around products of comparable quality (White 2002). From this perspective, the three sub-networks then correspond more broadly to three markets, which we call respectively "nearby", "mixed" and "centralised", connected by a few operators but also by a physical location, the Montpellier MIN. More precisely, the three markets are interconnected through two sites located at this MIN: the producers' floor and the wholesalers' floor (Fig. 6).

These three types of markets each correspond to types of products, suppliers, flows, chains and relationships (Table 2).

Hence, our analysis highlights more precisely that resilience is mainly covered by the suppliers (producers and wholesalers) of the mixed market, capable of mobilising, in the event of risks to their production or their own suppliers, the supply of the local market and/or the centralised market. The key position of these operators can be seen as a source of vulnerability. However, their ability to connect these markets, coupled with their relevant number (13

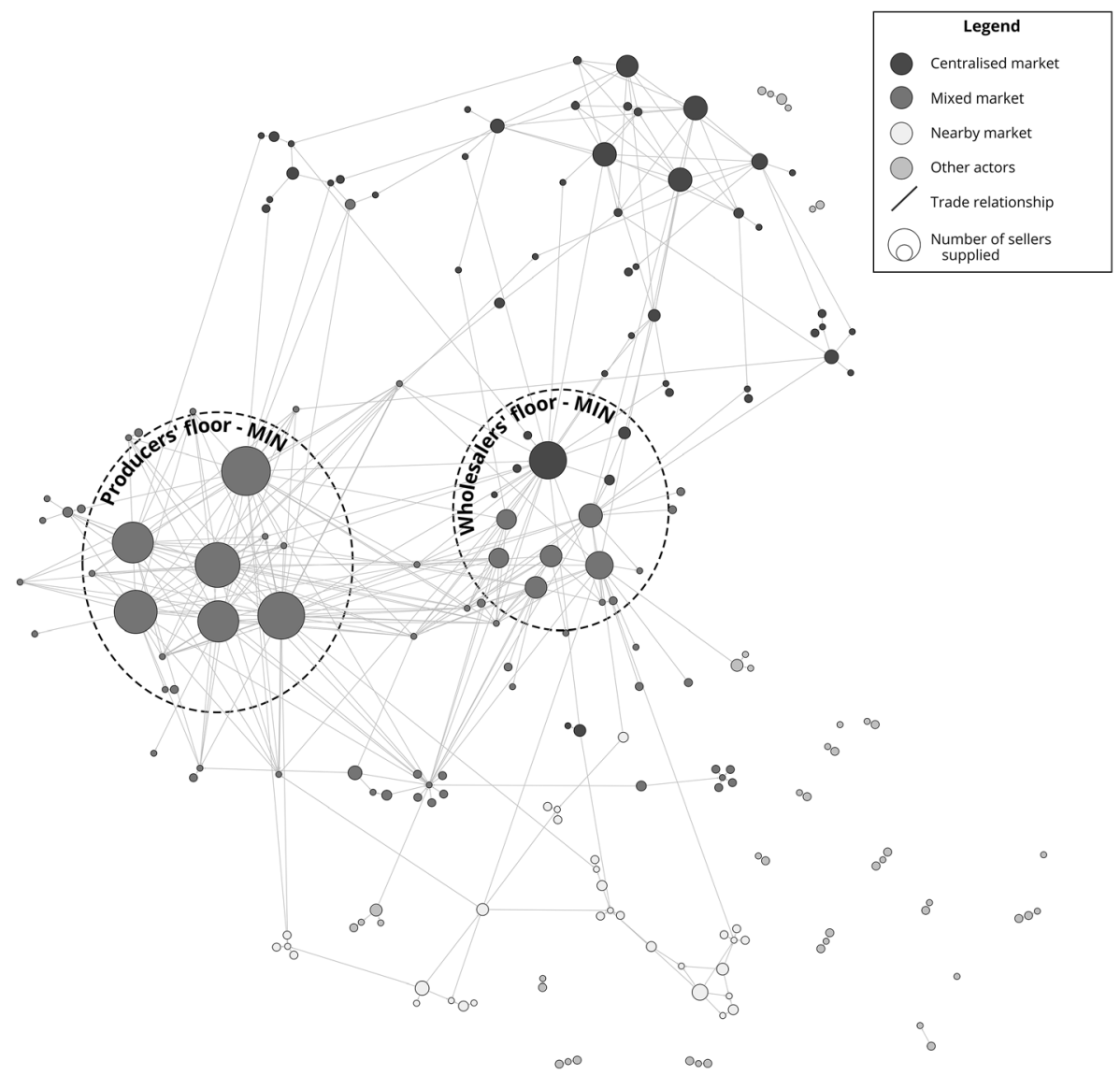

Fig.6 A tomato supply system in Montpellier structured around three markets and the Montpellier MIN. Source: authors 
Table 2 Characterisation of the three types of markets coexisting in the tomato supply for Montpellier

\begin{tabular}{|c|c|c|c|}
\hline & Nearby market & Mixed market & Centralised market \\
\hline $\begin{array}{l}\text { Range of } \\
\text { tomatoes and } \\
\text { varieties } \\
\text { observed } \\
\text { (main) }\end{array}$ & Reduced, true old varieties & $\begin{array}{l}\text { Medium, modern } \\
\text { varieties, true and } \\
\text { false old varieties }\end{array}$ & $\begin{array}{l}\text { Large, modern varieties and } \\
\text { false old varieties }\end{array}$ \\
\hline $\begin{array}{l}\text { Suppliers } \\
\text { (main) }\end{array}$ & Local producers & $\begin{array}{l}\text { Local producers } \\
\text { Regional wholesalers }\end{array}$ & $\begin{array}{l}\text { Central purchasing office } \\
\text { Regional wholesalers }\end{array}$ \\
\hline $\begin{array}{l}\text { Flows and } \\
\text { chains (main) }\end{array}$ & $\begin{array}{l}\text { Local, direct selling and short } \\
\text { chains } \\
\text { Origin in Montpellier area }\end{array}$ & $\begin{array}{l}\text { Local, short and long } \\
\text { chains } \\
\text { Origin in Montpellier } \\
\text { area, south-west and } \\
\text { Provence }\end{array}$ & $\begin{array}{l}\text { National, long chains } \\
\text { Origin in south-west and Brit- } \\
\text { tany }\end{array}$ \\
\hline $\begin{array}{l}\text { Relationships } \\
\text { between } \\
\text { /sellers and } \\
\text { suppliers }\end{array}$ & $\begin{array}{l}\text { - Strong links (market and } \\
\text { personal relationships) with } \\
\text { producers } \\
\text { - Commitment of certain sellers } \\
\text { to secure the offer (planning, } \\
\text { oral contract, etc.) } \\
\text { - Solidarity of certain sellers in } \\
\text { the event of production } \\
\text { contingencies (alternative to } \\
\text { "plan B") }\end{array}$ & $\begin{array}{l}\text { - Strong links (market } \\
\text { and personal } \\
\text { relationships) with } \\
\text { producers } \\
\text { - Weak links (functional } \\
\text { relationships) with } \\
\text { the intermediary } \\
\text { (wholesaler) }\end{array}$ & $\begin{array}{l}\text { - Little direct contact with a } \\
\text { central purchasing office, } \\
\text { regular change of contact } \\
\text { persons } \\
\text { - Strong links with certain local } \\
\text { wholesalers capable of } \\
\text { reactivity ("plan B") } \\
\text { - Some weak links, often } \\
\text { considered complex, with } \\
\text { local producers but little } \\
\text { long-term commitment }\end{array}$ \\
\hline
\end{tabular}

according to our study, which is not exhaustive) and their diverse statuses, makes the supply system more resilient than a system made up of unconnected markets or connected only through a very small number of operators would be, even with the same status. While the location of these operators in the same place may also raise questions - in the event of a blockade of the site by demonstrators or flooding, for example - this vulnerability is offset by the fact that some of them already market tomatoes outside such sites (sales on the farm or from another storage site).

Moreover, our surveys show that the sellers and wholesalers involved in this mixed market compete strongly with each other and with those of the local market to develop organic and local supply, which is further encouraged by the food policy implemented for several years by the City of Montpellier. Beyond creating tensions between operators, these practices destabilise local producers who do not market through the MIN: despite the interest in their production, they do not feel in a position of strength and do not necessarily have the means to respond or negotiate. Above all, visibility is lacking regarding the commitments that buyers on this market will actually make. From the point of view of resilience, this competition is likely to change the morphology of the supply

\footnotetext{
${ }^{0}$ With a few adjustments based on our in-depth knowledge of the field, e.g. weighting volumes obtained from certain "atypical" businesses (e.g. one of the city's local produce shops is very successful, its volumes do not correspond to the average sales of this type a shop).
} 
Table 3 Correspondence between the categories of trade taken into account by the CCI and the points of sale considered in this study

\begin{tabular}{ll}
\hline CCI categories & Corresponding categories considered in this study \\
\hline Hypermarkets & Hypermarkets \\
Covered and open-air markets & Covered and open-air markets \\
Specialised shops & Organic shops, local food shops, greengrocers \\
Supermarkets & Supermarkets, grocery shops \\
Hard discount & Hard discount \\
Other (convenience shops, & Independent grocers, other (gardening shop, bulk shop) \\
\multicolumn{1}{c}{ groceries) } & Specialised supermarkets (specialised food supermarkets) \\
GSSA & Not surveyed \\
Supermarkets drive-through & Direct selling structures, outside open-air markets (AMAP, food baskets, \\
Not taken into account & on-farm sales) \\
\end{tabular}

network, by destructuring the mixed market on which the coexistence of the different markets, which have hitherto been complementary, is based.

\section{Volumes that confirm the importance of coexistence}

In line with the work carried out in New York, our objective was not only to describe the city's supply system but also to quantify the volumes circulating in the chains so as to better understand the value of their coexistence from a resilience perspective. Data on volumes were difficult to obtain from open-air and covered market stands, but was easily collected in other types of shops, including specialised supermarkets and supermarkets, with some department heads or shop managers even providing us with spread sheets showing their sales, thus showing a greater openness than had previously been observed (Brand 2015). On the basis of the sample surveyed, we extrapolated the volumes sold on a citywide scale, also relying on an estimate of the fruit and vegetable market shares of the different types of shops located within the area of study, carried out by the Chamber of Commerce and Industry (CCI) in 2014 and updated by the latter with 2018 population data. We have hypothesised that the volume share for each type of trade corresponds to the associated market share, which could be discussed but would, according to the CCI experts, be "realistic". We therefore extrapolated the data collected from the 81 points of sale from the total population estimated from the SIRENE $^{8}$ database and field observations, and compared our extrapolations with the volume shares of the various businesses based on CCI data. This comparison first forced us to cross-reference the categories of trade used by the CCI with the categories of points of sale that we had selected for the study (Table 3). This led us to highlight the CCI's failure to take into account direct selling structures (except for producers at the markets), which were less developed in 2014 but represented a significant volume share

\footnotetext{
${ }^{8}$ With a few adjustments based on our in-depth knowledge of the field, e.g. weighting volumes obtained from certain "atypical" businesses (e.g. one of the city's local produce shops is very successful, its volumes do not correspond to the average sales of this type a shop).
} 
in 2019 (Table 4). We have therefore added a specific category to those established by the CCI.

The data extrapolated from our sample are therefore broadly consistent with the estimate of volumes by type of trade made from the CCI data, which lends credibility to their validity. The total volume is larger than that estimated from the CCI because it is an average over the year, whereas we estimated averages during the production season. The other difference is due to the respective shares of specialised supermarkets and direct selling structures outside the open-air markets, which are significant according to our survey: these reflect the growing importance of such types of points of sale in recent years (since 2014), a trend highlighted both by national studies (Chiffoleau 2019) and by the local experts to whom we have submitted these results.

On this basis, we have also extrapolated data on the origins of tomatoes and the length of supply chains mobilised by sellers. This calculation confirms the importance of short chains (46\% of volume, Fig. 7) and local supply (43\%, Fig. 8) in Montpellier's in-season tomato supply system.

\section{Lessons from the study and perspectives}

Using the tomato points of sale located in our area of study, our approach aimed to trace the supply chains mobilised, with the objective of evaluating three criteria that define the actual resilience of a city's supply system: (i) the diversity of suppliers and their location in space, in current situations and in the event of disruption; (ii) the balance between local and non-local products, as well as between short and long chains; and (iii) the intensity of the links within the chains and the morphology of the network of relationships between the actors contributing to the city's supply. In the light of these three criteria, the analysis highlights the following: (i) an average number of suppliers per point of sale that is rather low but fairly consistent throughout the city; suppliers connected to three different production zones currently; few alternative suppliers in the

Table 4 Extrapolation of the tomato volumes sold in Montpellier by the type of point of sale. Source: Authors

\begin{tabular}{lllll}
\hline Points of sale categories & $\begin{array}{l}\mathrm{kg} / \text { week/trade } \\
\text { CCI }\end{array}$ & $\begin{array}{l}\text { Percentage } \\
\text { CCI }\end{array}$ & $\begin{array}{l}\text { kg/week/point of sale } \\
\text { Survey }\end{array}$ & $\begin{array}{l}\text { Percentage } \\
\text { survey }\end{array}$ \\
\hline $\begin{array}{l}\text { Hypermarkets } \\
\text { Covered and open-air }\end{array} \quad 29,302$ & $31 \%$ & 32,143 & $26 \%$ \\
$\quad 26,976$ & $29 \%$ & 26,968 & $22 \%$ \\
markets & 19,278 & $21 \%$ & 28,423 & $23 \%$ \\
Superialised shops & 7707 & $8 \%$ & 11,173 & $9 \%$ \\
Hard discount & 5472 & $6 \%$ & 4840 & $4 \%$ \\
Other & 2799 & $3 \%$ & 5592 & $5 \%$ \\
Specialised supermarkets & 777 & $1 \%$ & 6200 & $5 \%$ \\
Supermarkets drive-through & 605 & $1 \%$ & Not surveyed & Not surveyed \\
Direct selling outside & Not taken into & Not taken into account & 8096 & $7 \%$ \\
$\quad$ open-air markets & account & & & $100 \%$ \\
Total & $\mathbf{9 2 , 9 1 5}$ & $100 \%$ & $\mathbf{1 2 3 , 4 3 5}$ & \\
\hline
\end{tabular}




\section{Length of the supply chains}
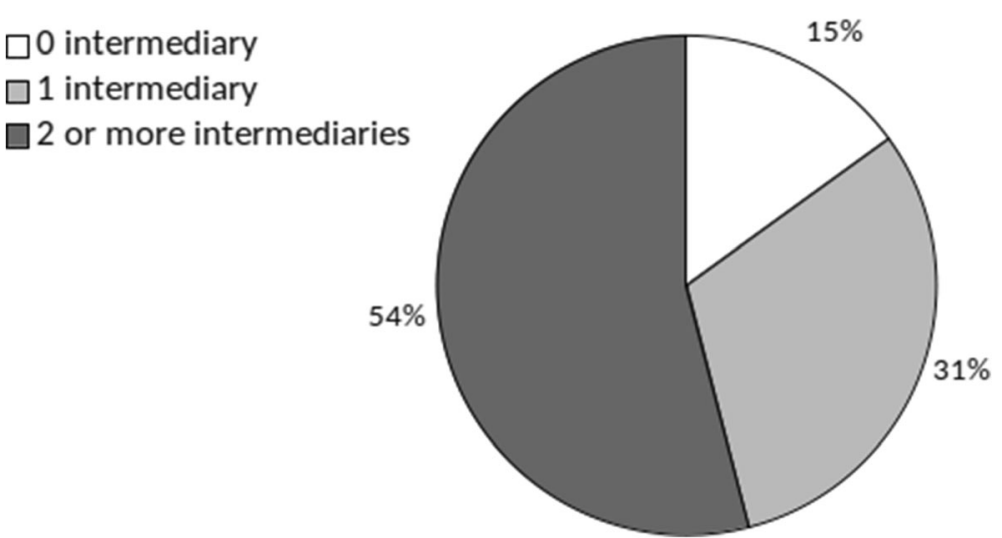

Fig. 7 Distribution of tomato volumes sold in Montpellier according to the length of the supply chain (Fig. 7). Source: authors. NB. Local food here corresponds to an $80-\mathrm{km}$ radius around the point of sale

event of a disruption, but by choice in some cases; (ii) almost half of the supply that is local and in short chains (in season); (iii) strong links supporting local supply and responsiveness in the event of a disruption; a network made up of three sub-parts connected by more than ten producers and wholesalers and through a main exchange point, the MIN.

The evaluation of these criteria in the case of Montpellier thus leads to the conclusion, in light of the previous literature on urban supply, that the tomato supply system has, in season, important assets from the resilience standpoint, particularly because of the quantitative importance of local supply, highlighted in the work on foodsheds and urban metabolism. Above all, the analysis of these criteria leads us more broadly to show that the resilience of the city's supply is based on the articulation of three distinct and complementary markets, fostered by a diversity of intermediaries and a place of

\section{Production location}

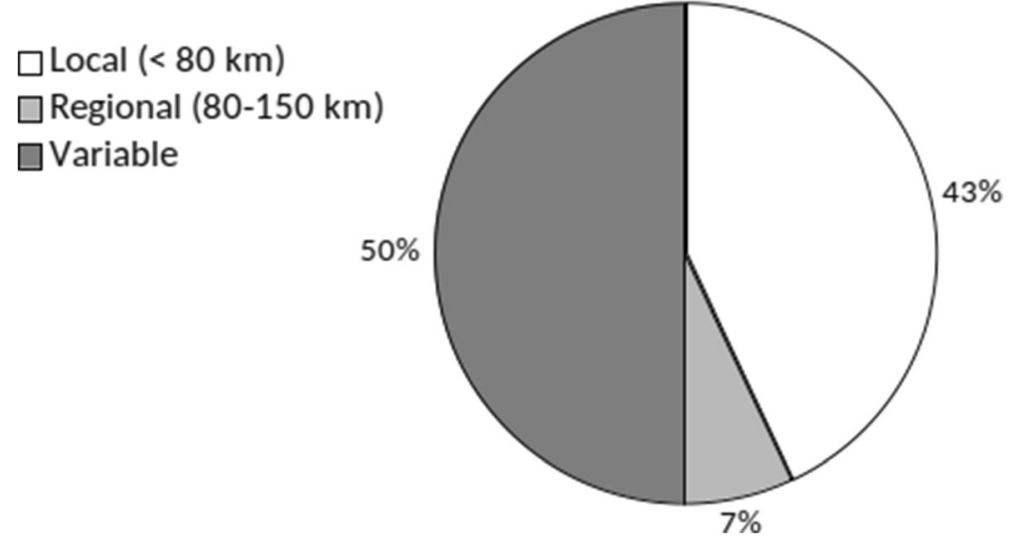

Fig. 8 Distribution of tomato production location (Fig. 8) (tomato season period: June-September). Source: authors. NB. Local food here corresponds to an $80-\mathrm{km}$ radius around the point of sale 
exchange allowing this diversity. Therefore, this research constitutes an original contribution to the intersection of work on urban supply resilience and on coexistence in food systems, as well as on the development of urban food policies, even if it has several limitations and possible lines for further study.

First of all, by focusing on the scale of the city's consumption basin, our study makes it possible to understand the strengths and vulnerabilities of the market system built around the supply chains mobilised by sellers in terms of resilience: these chains are not independent insofar as they can rely on the same suppliers and the same production or exchange locations. A high level of resilience at the level of each chain, fostered by a large number of suppliers and a strong link between seller and supplier, does not lead us to conclude that there is a high level of resilience in terms of the supply system. This scale, which is not addressed in the management science literature on supply chains, remains scarcely considered in studies of cities, beyond highlighting common vulnerabilities related to the freight transportation network-although the New York study laid the groundwork to delve further into the topic. The coexistence of different supply chains is therefore not sufficient to ensure the resilience of a city's supply since they are not necessarily complementary. At the end of our study, the resilience of the city's supply system relies more on the articulation between distinct markets, subject to different hazards. However, this linkage must not rely on an insufficient number of operators or places of exchange. In all cases, it remains vulnerable, subject to the strategies of the actors and to changes in the context. In this case, the context is marked by new competition for organic and local supplies. This point refers more broadly, in economic sociology, to the possible phenomena of "siphoning" between interconnected markets, i.e. that actors linked to several markets seek to capture the supply of one market in favour of another, which may call for the implementation of rules to stabilise the coexistence of markets (White 2002).

Our analysis therefore calls for an in-depth examination of the strengths and vulnerabilities of the market system that underpin the resilience of the supply system. In particular, it is a question of delving deeper into the spatialisation of the flows supplying the city, by identifying the routes used, the warehouses mobilised, and so on. In addition to assessing the capacity of each infrastructure to withstand risks using a supply chain approach, the aim is to take into account the low or high redundancy of the infrastructures mobilised on the scale of all the points of sale in the city. The strengths and vulnerabilities of the system of relationships between actors also need to be examined in greater depth: in our study, the objective of collecting both qualitative and quantitative data during a single interview, sometimes limited in time taking into account the trader's availability, did not allow all fields to be precisely addressed.

Furthermore, according to the definition initially adopted that resilience is also the ability of outlets to provide appropriate food, the analysis of the system must be continued by taking the quality of the products circulating in the system into further account, the transport of which changes the initial quality. In the case of the centralised market, we observed the common practice of harvesting the crop before full maturity and storing it at too low a temperature for several days. In the case of the mixed market, we noted storage at too high a temperature and long exposure to the sun for tomatoes: in both cases, these practices were analysed as unfavourable to the maintenance of the tomatoes' organoleptic and nutritional qualities (Kojo Arah et al. 2015). If these practices do not affect the quantity supplied, do they fully contribute to providing a 
healthy and nutritious supply, adapted to consumer needs and preferences? How would these markets withstand increased information on differences in nutritional quality among tomatoes? The nutrition-health dimension is prominent in consumption trends ${ }^{9}$ and is taking on new importance in urban food policies (IPES-Food 2017), which justifies the interest in deepening the impact of chains and associated logistics on the nutritional quality of products.

With regard to urban food policies, more directly, and the relocation issues often associated with them, our analysis confirms the important role of economic intermediaries (retailers, wholesalers, etc.) in enhancing the value of local agriculture (Praly et al. 2014; Brives et al. 2017; Loconto et al. 2018), even if different values may be associated. Those actors are still scarcely considered in the literature on alternative food systems and hardly considered by public actors and citizens committed to relocation (Brand 2015; Baritaux and Billion 2018). However, we confirmed that despite the willingness of some to buy local, they do not always have room to manoeuvre. Our surveys also highlight a constraint that we have not identified to date in literature on retailers' supply strategies: the product promotion catalogue distributed by all mass distribution and hard discount retailers. Its publication 6 weeks in advance leads sellers to prefer tomatoes grown in other countries at the beginning and the end of the season. These will indeed be available with certainty, whereas the French tomato will not necessarily be available. According to our interviewees, shop managers do not want to take a risk by misleading the customer, noting that "many customers come to the shop with their catalogue and reproach us for not having the origin indicated in it", thus confirming a growing consumer interest in the origin of food products (Tavoularis et al. 2015).

With regard to intermediaries, our analysis ends by calling for further attention to be paid to the role that MINs play or could play in the implementation of a food policy that would strengthen the resilience of the city's supply. While research has shown the key role of MINs in the history of fruit and vegetable markets (Bernard de Raymond 2011), it also points out that these trading places have been bypassed since the 1970 s - producer groups have increasingly tended to supply sellers directly without going through the MIN. Our study, based on qualitative and quantitative data, nuances this trend by pointing out that in the case of Montpellier, it remains a central nodal point for in-season tomato trade, in terms of flows as well as for relationships. Is this phenomenon specific to Montpellier? The claim by the National Federation of Wholesale Markets to be major players in the nearby market ${ }^{10}$ invites us to strengthen their current and potential role, not only in supplying the city but also, more broadly, in organising complementarity and managing competition between different markets as a public-private system.

\footnotetext{
${ }^{9}$ Ipsos survey, 2017.

${ }^{10}$ French National Wholesale Markets Day: "Wholesale markets, France's leading platforms for the supply of local products" (2018/11/30) http://marchesdegros.com/journee-nationale/
} 


\section{Conclusion}

Based on the example of Montpellier, this article proposes and tests an approach aimed at characterising a city's supply system and analysing various criteria defining its actual resilience. Anchored in economic and network sociology, the approach proposed here has been enriched by the point of view of management sciences and geomatics, leading us to consider resilience through the actors, strategies and flows structuring the city's supply system. This collaboration between disciplines and between researchers must be continued and strengthened to better take into account the strengths and vulnerabilities of such systems at the citywide scale. Despite its limitations, the research presented here is one of the first contributions seeking both to conceptualise a city's supply system and to produce quantitative data from a large sample. It is part of a field of research under construction on urban food resilience, while at the same time offering new insights on the theme of coexistence in food systems by shifting the analysis towards the articulation of different types of markets. From the perspective of public action, the complementarity between long and short chains, local and global production, a challenge for urban food policies and, more broadly in France, for Territorial Food Projects (Maréchal et al. 2019), proves to be real here, even if the results will most certainly be different in winter, as well as for other products. This complementarity nevertheless appears threatened by new competition between actors seeking to meet the growing demand for organic and local products, which could destabilise the coexistence between markets and the resilience it allows. Public actors can then take up this issue and, through regulatory tools such as the MIN in particular, seek to limit the phenomenon of siphoning between markets (White 2002).

\section{Compliance with ethical standards}

Conflict of interest The authors declare that they have no conflict of interest.

\section{References}

Baritaux, V., \& Billion, C. (2018). Rôle et place des détaillants et grossistes indépendants dans la relocalisation des systèmes alimentaires : perspectives de recherche. Revue de l'organisation responsable, 13, 17-28.

Barles, S. (2017). Écologie territoriale et métabolisme urbain : quelques enjeux de la transition socioécologique. Revue d'Économie Régionale and Urbaine, 5, 819-836.

Bernard de Raymond, A. (2011). Arrangements for market intermediation and policies. Modernizing the fruit and vegetable market in France, 1950-1980. Sociologie du travail, 53, 19-37.

Billen, G., Barles, S., Garnier, J., Rouillard, J., \& Benoit, P. (2009). The food-print of Paris: long-term reconstruction of the nitrogen flows imported into the city from its rural hinterland. Regional Environmental Change, 9(1), 13-24.

Billen, G., Barles, S., Chatzimpiros, P., \& Garnier, J. (2012). Grain, meat and vegetables to feed Paris: where did and do they come from? Localising Paris food supply areas from the eighteenth to the twenty-first century. Regional Environmental Change, 12(2), 325-335.

Bognon, S. (2015). Nourrir Paris : trajectoire de l'approvisionnement alimentaire de la métropole capitale, de la fin de l'Ancien Régime à nos jours. Géocarrefour, 90(2), 163-171.

Brand, C. (2015). Alimentation et métropolisation : repenser le territoire à l'aune d'une problématique vitale oubliée, Thèse de doctorat de géographie, Université de Grenoble-Alpes.

Brives, H., Chazoule, C., Fleury, F., \& Vandenbroucke, P. (2017). La notion d'“agriculture du milieu" est-elle opérante pour l'analyse de l'agriculture de Rhône-Alpes? Economie Rurale, 357-358, 41-56. 
Burt, R. S. (1995). Structural holes: the social structure of competition. Cambridge: Harvard University Press. Carey, J. (2011). Who feeds Bristol? Toward a resilient food plan. Bristol partnership, Research report, https://www.bristol.gov.uk/whofeedsbristol

Chiffoleau, Y. (2019). Les circuits courts alimentaires. Entre marché et innovation sociale. Toulouse: Erès.

Darrot, C. (2014). Rennes, ville vivrière ? Une prospective proposée par les étudiants de l'option « Agriculture Durable et Développement Territorial » d'Agrocampus Ouest. Pour, 224(4), 405.

Debarle, G. (2019). La biodiversité au service du goût. Quelle place pour les anciennes variétés de fruits et de légumes? In Situ, 41. https://journals.openedition.org/insitu/25953

Debuisson, M. (2014). Les modes d'interaction pour une dynamique territoriale soutenable : un apport à l'écologie territoriale. Thèse de doctorat de l'UTT Développement Durable. Sciences de l'Homme et Société. Université de Technologie de Troyes.

Degenne, A., \& Forsé, M. (1994). L'analyse des réseaux sociaux. Paris: Armand Colin.

Douard, J.-P., Heitz, M., \& Cliquet, G. (2015). L'attraction commerciale revisitée : de la gravitation aux flux d'achat, une application du géomarketing. Recherche et Applications en Marketing, 30(1), 118-137.

Favereau, O., \& Lazega, E. (Éd.). (2002). Conventions and structures in economic organization: markets, networks, and hierarchies. Cheltenham, UK ; Northampton, Mass: Edward Elgar.

Fournier, S., \& Touzard, J.-M. (2014). La complexité des systèmes alimentaires: un atout pour la sécurité alimentaire? VertigO - la revue électronique en sciences de l'environnement, 14(1). https://www.erudit. org/en/journals/vertigo/2014-v14-n1-vertigo01649/1027948ar.pdf

FranceAgriMer (2018). Les filières des fruits et légumes - données 2017. https:/www.franceagrimer. fr/fam/content/download/61484/document/chiffres\%20c1\%C3\%A9s\%20FL\%202017.pdf?version=10

Gasselin, P. (2017). Modèles de développement, coexistence et confrontation des modèles agricoles et alimentaires : vers un agenda de recherche. Séminaire de la Faculté des bioingénieurs et du "Earth and Life Institute": Louvain-La-Neuve, Belgique.

Granovetter, M. S. (1973). The strength of weak ties. American Journal of Sociology, 78(6), 1360-1380.

Granovetter, M. S. (1985). Economic action and social structure: the problem of Embeddedness. American Journal of Sociology, 91(3), 481-510.

Hecht, A. A., Biehl, E., Barnett D. J., \& Neff R. A. (2018). Urban Food Supply Chain Resilience for Crises Threatening Food Security: A Qualitative Study. Journal of the Academy of Nutrition and Dietetics, 119(2), 211-224.

Hedden, W. P. (1929). How great cities are fed. Boston, Mass: D. C. heath and company.

Hervieu, B., \& Purseigle, F. (2015). The sociology of agricultural worlds: from a sociology of change to a sociology of coexistence. Review of Agricultural and Environmental Studies, 96(1),59-90.

Hohenstein, N. O., Feisel, E., Hartmann, E., \& Giunipero, L. (2015). Research on the phenomenon of supply chain resilience: a systematic review and paths for further investigation. International Journal of Physical Distribution and Logistics Management, 45(1/2), 90-117.

Horst, M., \& Gaolach, B. (2015). The potential of local food systems in North America: a review of foodshed analyses. Renewable Agriculture and Food Systems, 30(05), 399-407.

IPES-Food, 2017. What makes urban food policy happen? Insights from five case studies. Report by the International Panel of Experts on Sustainable Food Systems, June, http://www.ipes-food. org/images/Reports/Cities_full.pdf

Kloppenburg, J., Hendrickson, J., \& Stevenson, G. W. (1996). Coming in to the foodshed. Agriculture and Human Values, 13(3), 33-42.

Kojo Arah, I., Amalgo, H., Kodzo Kumah, E., \& Ofori, H. (2015). Preharvest and postharvest factors affecting the quality and shelf life of harvested tomatoes: a mini review. International Journal of Agronomy, 2015, 4780416 pages.

Kremer, P., \& De Liberty, T. L. (2011). Local food practices and growing potential: mapping the case of Philadelphia. Applied Geography, 31(4), 1252-1261.

Li, W., Li, L., Goodchild, M., \& Anselin, L. (2013). A geospatial cyberinfrastructure for urban economic analysis and spatial decision-making. ISPRS International Journal of Geo-Information, 2(2), 413-431.

Linou, S. (2019). Résilience alimentaire et sécurité nationale. Paris: The Book Edition.

Loconto, A., Jimenez, A., \& Vandecandelaere, E. (2018). Constructing markets for agroecology - an analysis of diverse options for marketing products from agroecology. FAO: Rome.

Maréchal, G., Noël, J., \& Wallet, F. (2019). Les projets alimentaires territoriaux (PAT), entre rupture, transition et immobilisme? Pour, 234-235, 261-270.

Marie, M., Guillemin, P., Bermond, M., \& Guennoc, D. (2017). Evaluation de la consommation alimentaire dans onze aires urbaines françaises. Les défis de développement pour les villes et les régions dans une Europe en mutation, ASRDLF / ERSA-GR, July, Athens, Greece. 
Morgan, K., \& Sonnino, R. (2010). The urban foodscape: world cities and the new food equation. Cambridge Journal of Regions, Economy and Society, 3(2), 209-224.

NYC Economic Development Corporation, \& NYC Mayor Office of Recovery and Resiliency. (2016). Five Borough Food Flow - 2016. New York City: Food Distribution and Resilience Study Results.

Peters, C. J., Bills, N. L., Lembo, A. J., Wilkins, J. L., \& Fick, G. W. (2009a). Mapping potential foodsheds in New York State: a spatial model for evaluating the capacity to localize food production. Renewable Agriculture and Food Systems, 24(01), 72-84.

Peters, C. J., Bills, N. L., Wilkins, J. L., \& Fick, G. W. (2009b). Foodshed analysis and its relevance to sustainability. Renewable Agriculture and Food Systems, 24(01), 1-7.

Pettit, T. J., Croxton, K. L., \& Fiksel, J. (2013). Ensuring supply chain resilience: development and implementation of an assessment tool. Journal of Business Logistics, 34(1), 46-76.

Polanyi, K. (1944). The great transformation: the political and economic origins of our time (2nd Beacon Paperback ed.). Boston, MA: Beacon Press.

Polge, E., Torre, A., \& Wallet, F. (2018). Coexistence et hybridation des modèles agricoles en Amazonie orientale. L'exemple la production laitière dans deux villages de la « commune verte » de Paragominas. Économie rurale, 366, 41-60.

Praly, C., Chazoule, C., Delfosse, C., \& Mundler, P. (2014). Les circuits de proximité, cadre d'analyse de la relocalisation des circuits alimentaires. Géographie, économie, société, 16(4), 455-478.

Saucède, F. (2010). Le management de la spécificité des rayons fruits et légumes : une modélisation inductive fondée sur la méthode des cas (thesis). Université Montpellier 3.

Smith, K., Lawrence, G., MacMahon, A., Muller, J., \& Brady, M. (2016). The resilience of long and short food chains: a case study of flooding in Queensland, Australia. Agriculture and Human Values, 33(1), $45-60$.

Sonnino, R. (2016). The new geography of food security: exploring the potential of urban food strategies. The Geographical Journal, 182(2), 190-200.

Steel, C. (2008). Hungry city: how food shapes our lives. London: Chatto \& Windus.

Stolt, J., \& Grant, D. B. (2017). Investigating supply chain resilience in small and medium-sized family Finnish firms. In G. Paché (Ed.), Images de la logistique: éclairages managériaux et sociétaux (pp. 123129). Aix-en-Provence: Presses universitaires d'Aix-Marseille.

Tavoularis, G., Hébel, P., Billmann, M., \& Lelarge, C. (2015). Comment a évolué sur les deux dernières décennies la relation à la qualité pour les consommateurs français? Cahier de recherche du CREDOC, C327, 4. Décembre 2015. https://www.credoc.fr/publications/comment-a-evolue-sur-les-deux-dernieresdecennies-la-relation-a-la-qualite-pour-les-consommateurs-francais.

Tedesco, C., Petit, C., Billen, G., Garnier, J., \& Personne, E. (2017). Potential for recoupling production and consumption in peri-urban territories: the case-study of the Saclay plateau near Paris, France. Food Policy, $69,35-45$.

Tendall, D. M., Joerin, J., Kopainsky, B., Edwards, P., Shreck, A., Le, Q. B., Kruetli, P., Grant, M., \& Six, J. (2015). Food system resilience: defining the concept. Global Food Security, 6, 17-23.

White, H. C. (2002). Markets from networks: socioeconomic models of production. Princeton: Princeton University Press.

Zasada, I., Schmutz, U., Wascher, D., Kneafsey, M., Corsi, S., Mazzocchi, C., \& Piorr, A. (2019). Food beyond the city - analysing foodsheds and self-sufficiency for different food system scenarios in European metropolitan regions. City, Culture and Society, 16, 25-35.

Publisher's note Springer Nature remains neutral with regard to jurisdictional claims in published maps and institutional affiliations. 